\title{
TUNGSTEN-STEEL AND TUNGSTEN-CHROMIUM COMPOSITES PREPARED BY RF PLASMA SPRAYING
}

\author{
${ }^{1}$ Jiří MATĚJIČEK, ${ }^{1} J a k u b$ KLEČKA, ${ }^{1} J a n$ CIZEK, 'Jakub VEVERKA, ${ }^{1}$ Monika VILÉMOVÁ, \\ ${ }^{1}$ Tomáš CHRÁSKA, ${ }^{2}$ Vishnu GANESH \\ ${ }^{1}$ Institute of Plasma Physics, Czech Academy of Sciences, Prague, Czech Republic, EU, \\ matejicek@ipp.cas.cz,klecka@ipp.cas.cz,cizek@ipp.cas.cz,veverka@ipp.cas.cz,vilemova@ipp.cas.cz, \\ chraskat@ipp.cas.cz \\ ${ }^{2}$ Forschungszentrum Jülich, Jülich, Germany, EU, \\ v.ganesh@fz-juelich.de
}

https://doi.org/10.37904/metal.2020.3548

\begin{abstract}
For future fusion reactors, materials able to withstand harsh environments are needed. In particular, this concerns the plasma-facing components which are foreseen to consist of tungsten-based plasma-facing armor and structural and cooling part made of steel. Currently, joining of these materials presents a significant challenge. The stress concentration at their interface, which arises due to thermal exposure and the difference in thermal and mechanical properties, can be reduced by composite/graded interlayers. Plasma spraying is among the prospective technologies for their preparation. In this work, tungsten-steel and tungsten-chromium composites were prepared by radio-frequency inductively coupled plasma (RF-ICP) spraying. Initial optimization of the spraying process for pure materials as well as their mixtures was carried out. Basic characterization of the layers for their structure, porosity and composition is presented.
\end{abstract}

Keywords: Fusion materials, plasma-facing components, tungsten-steel composites, tungsten-chromium composites, plasma spraying

\section{INTRODUCTION}

Plasma-facing components for future fusion reactors will have to withstand extreme conditions that include high heat fluxes (both steady-state and thermal shocks) and bombardment of plasma species (ions, electrons, neutral atoms and high-energy neutrons) [1]. Tungsten is considered the prime candidate material for these components, particularly for its high melting point, high strength at elevated temperatures, resistance to sputtering, good thermal conductivity, etc. [2,3]. However, joining of tungsten as the plasma facing armor to the steel-based or copper-based structural or cooling system presents a significant challenge - in particular, the large difference in thermal expansion coefficients and moduli of elasticity leads to high stresses at the interface upon thermal loading [4]. Possible joining technologies include direct bonding, solid-state bonding or brazing with discrete interlayers or the use of graded interlayers consisting of only tungsten and steel or copper [4]. The use of additional materials is constrained by several factors, such as the requirement for low activation, temperature limitations, requirements for thermodynamic stability, high yield strength, etc. [4]. On the other hand, the graded interlayers replace the sharp interface with a smooth transition, thus reducing the stress concentration. An overview of several prospective fabrication technologies, such as plasma spraying, laser cladding, hot pressing and spark plasma sintering is given in [5]. The advantages of plasma spraying lie in its ability to cover large area, in a single-step technology (possibly eliminating the need for further bonding), as well as easy control of the compositional gradients [6]. Plasma sprayed tungsten-steel composites and graded 
layers were investigated e.g. in [7,8,9], plasma sprayed tungsten-copper in [10]. Most recently, first results on tungsten-chromium composites prepared by RF-ICP spraying [11] and cold spraying [12] were presented.

This work presents tungsten-steel and tungsten-chromium composites prepared by RF-ICP spraying. Compared to conventional direct current arc plasma spray systems, the distinct features of this technology include axial feeding of the powder, large volume and low velocity and energy density of the plasma, relatively long particle dwell time and controlled atmosphere chamber [13]. Examples of initial optimization are shown together with characteristic features of these coatings.

\section{EXPERIMENTAL}

\subsection{Sample preparation}

The coatings were sprayed using radio-frequency inductively coupled plasma system Tekna 15 (Tekna, Sherbrooke, Canada) in a controlled atmosphere chamber. The torch was operated at $15 \mathrm{~kW}$ power. Argon and hydrogen were used as the plasma forming gases, argon as a sheath and carrier gas. The chamber pressure was kept at $103.4 \mathrm{kPa}$. Spray distance of $70 \mathrm{~mm}$ was used. Other parameters that were varied for individual runs will be mentioned together with the results, where relevant. Two types of substrates were used: graphite discs of $60 \mathrm{~mm}$ diameter and $10 \mathrm{~mm}$ height, rotating around axis parallel with the plasma jet, and AISI 304 stainless steel of $60.6 \times 20 \times 3 \mathrm{~mm}$ dimensions, either rotating around axis perpendicular to the plasma jet or translating along this axis without rotation. The latter was placed in an in-house developed actively cooled substrate holder.

The following powders were used:

W: $<63 \mu \mathrm{m}$ (Osram, Towanda, USA); 10-20 $\mu \mathrm{m}$ (Global Tungsten and Powders, Bruntál, Czechia) steel: AISI 410, 53-90 $\mu \mathrm{m}$ (Flame Spray Technologies, Duiven, Netherlands)

Cr: $~ 30 \mu \mathrm{m}$ (US Research Nanomaterials, Houston, USA)

For the tungsten-steel composites, the $\mathrm{W}$ and steel powders were mixed with 50:50 volume ratio. For the tungsten-chromium composites, $\mathrm{W}$ and $\mathrm{Cr}$ powders were mixed with 75:25 weight ratio.

To check the thermal stability, a representative $\mathrm{W}-\mathrm{Cr}$ composite coating was annealed in vacuum at $1000{ }^{\circ} \mathrm{C}$ for $10 \mathrm{~h}$. Elemental analysis was then performed at the same location to detect possible changes.

\subsection{Coating characterization}

The structure of the coatings was observed using scanning electron microscopy (SEM; EVO MA 15, Carl Zeiss SMT, Oberkochen, Germany) on polished cross sections. Local elemental composition was determined using energy-dispersive spectrometry (EDS; XFlash 5010, Bruker, Karlsruhe, Germany) in the SEM. Porosity and percentage of the individual phases was determined by image analysis using ImageJ software (National Institute of Health, USA) on the SEM images. Phase identification was performed with the help of $x$-ray diffraction (XRD) using D8 Discover diffractometer (Bruker, Karlsruhe, Germany).

\section{RESULTS}

\subsection{Pure tungsten}

Figure 1 shows the cross section of a pure $\mathrm{W}$ coating (from the $<63 \mu \mathrm{m}$ powder) on a graphite substrate, resulting from the initial optimization [14]. This features high density, typical splat structure and columnar crystal grains having grown across several splat layer, indicating very good intersplat contact. Only some splat boundaries are visible. 

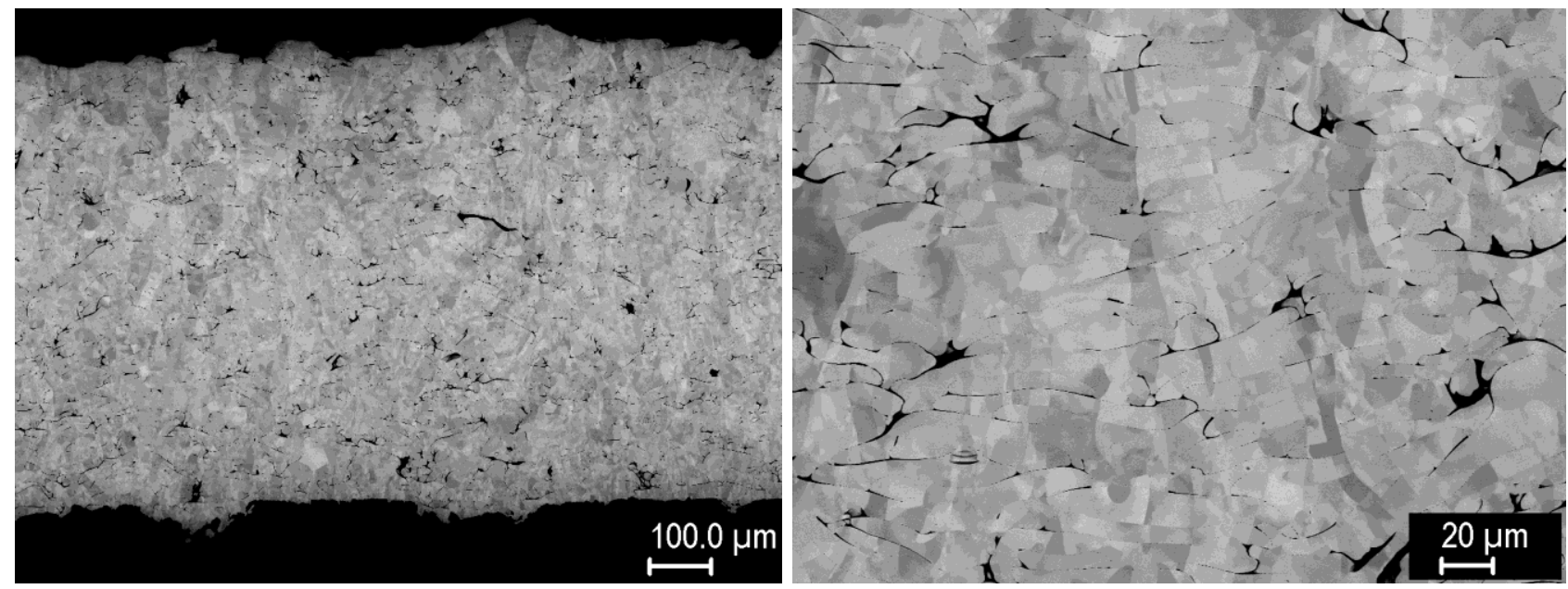

Figure 1 Cross sections of pure tungsten coating on a graphite substrate; a) overview, b) detail, [14].
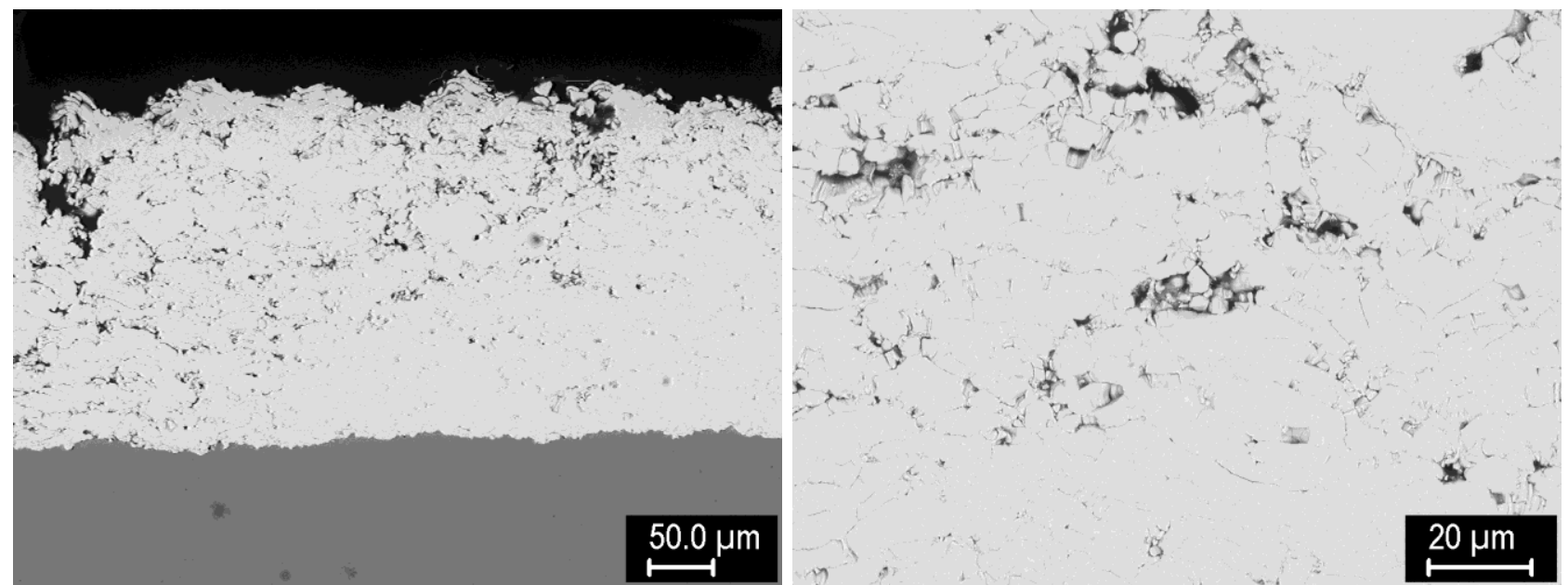

Figure 2 Cross sections of pure tungsten coating on a steel substrate; a) overview, b) detail.

Figure 2 shows the cross section of a pure $W$ coating (from the 10-20 $\mu \mathrm{m}$ powder) on a rotating steel substrate. Although still relatively dense, it has some regions with higher porosity (e.g. on the left of Figure $\mathbf{2 a}$ ). As seen in Figure $\mathbf{2 b}$ ), the splat boundaries are generally more distinct than in the previous case.

\subsection{Pure steel}

A representative cross section of pure steel coating on a graphite substrate is shown in Figure 3a). Very dense structure is observed, with occasional small pores; no splats/lamellae, typical for plasma sprayed coatings, can be discerned. Apparently, due to the high heat input from the torch, a melt layer was formed in which all deposited particles fused together. The surface roughness is likely a result of temporary arc attachment, causing localized surface erosion. This phenomenon was occasionally observed, however, no remedy against it was found so far. The detail in Figure 3b) shows an internal structure, which was infrequently observed, possibly a result of slow solidification. This was revealed due to metallographic preparation, and was not accompanied with any compositional inhomogeneity.

\subsection{Tungsten-steel composites}

Figure 4a) shows the cross section of the first W-steel composite prepared on a steel substrate. Tungsten particles exhibit typical splat structure with visible splat-splat interfaces, while the steel phase appears completely fused without any splat structure. The coating has overall porosity about $4 \%$, but both the pores 
and the phases are rather inhomogeneously distributed. Besides very dense regions, there are regions with rather large pores spanning several splat layers (Figure $\mathbf{4 b}$ ). Concerning the mixing of tungsten and steel, there are W-rich regions alternating with well mixed ones. Overall, the steel content was reduced compared to the feedstock, to about 30 volume \% in the coating. Partial evaporation of the steel particles may have been responsible for this. In the structure, no significant amount of intermetallics was observed. Only in some regions, a stronger local interdiffusion was observed, resulting in steel enrichment by tungsten (Figure 5a). Figure 5b) shows a surface of the same coating, revealing the large difference in splat size between steel and tungsten. This may be among the factors responsible for the inhomogeneity, but was necessitated by the large difference in melting points $\left(\sim 3370-3422^{\circ} \mathrm{C}\right.$ for tungsten [15,16], $1480-1530^{\circ} \mathrm{C}$ for 410 steel [15]).
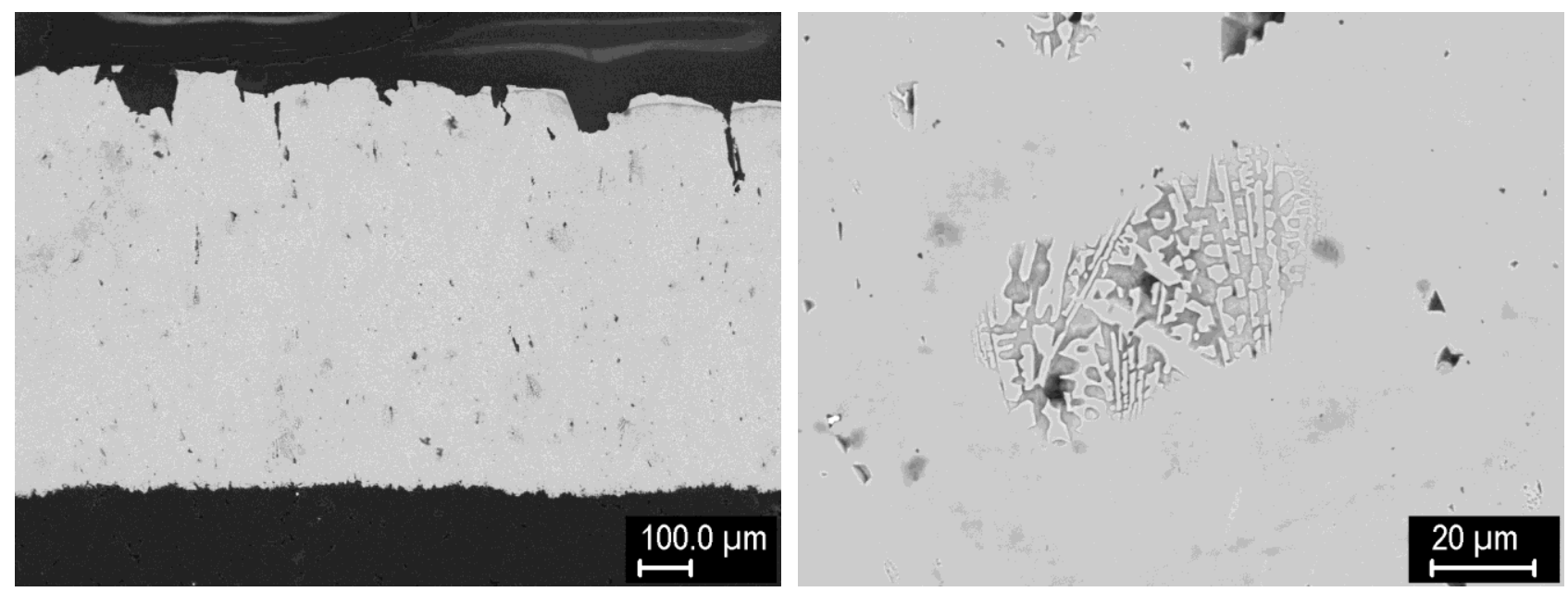

Figure 3 Cross sections of pure steel coating; a) overview, b) detail.
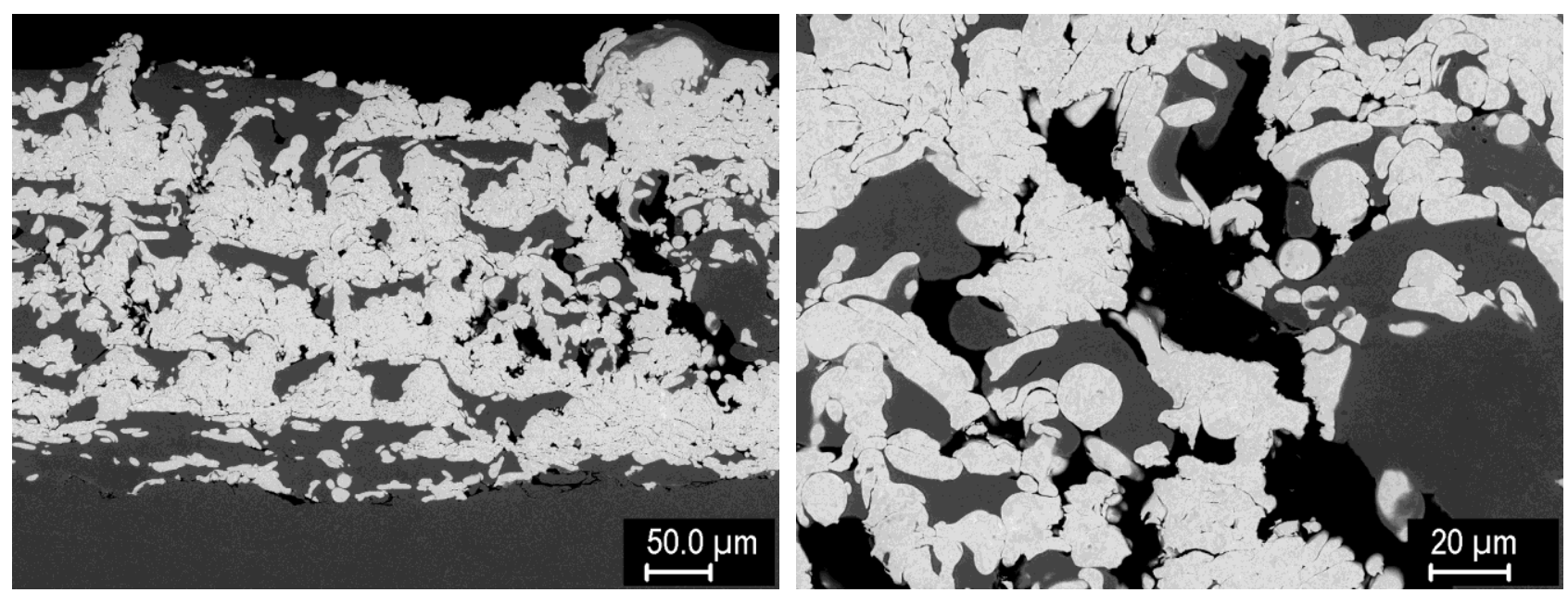

Figure 4 Cross sections of a tungsten-steel coating sprayed on a rotating cooled holder; a) overview, b) detail of region with large pores.

Figure 6 shows the cross section of another W-steel composite coating, sprayed on a steel substrate without rotation. This was done in an attempt to reduce the porosity by increasing the deposition temperature. In the near-substrate region, dense coating was formed (Figure 6a). At the tungsten-steel splat interfaces, intermetallic formation is observed, as a result of elevated temperature. This was identified by XRD as $\mathrm{Fe}_{7} \mathrm{~W}_{6}$. Farther away from the substrate, however, the porosity significantly increased (Figure 6b), possibly due to overheating and evaporation of the steel phase. The intermetallic layers were observed in this region as well. Several more coatings were prepared from the same powder mixture, using different combinations of cooled holder rotation and translation. All of them, however, featured the same issues as the two examples shown 
above, i.e. significant inhomogeneity in terms of porosity and phase distribution. This indicated the need for tighter control of the deposition temperature, which is the subject of ongoing activity.

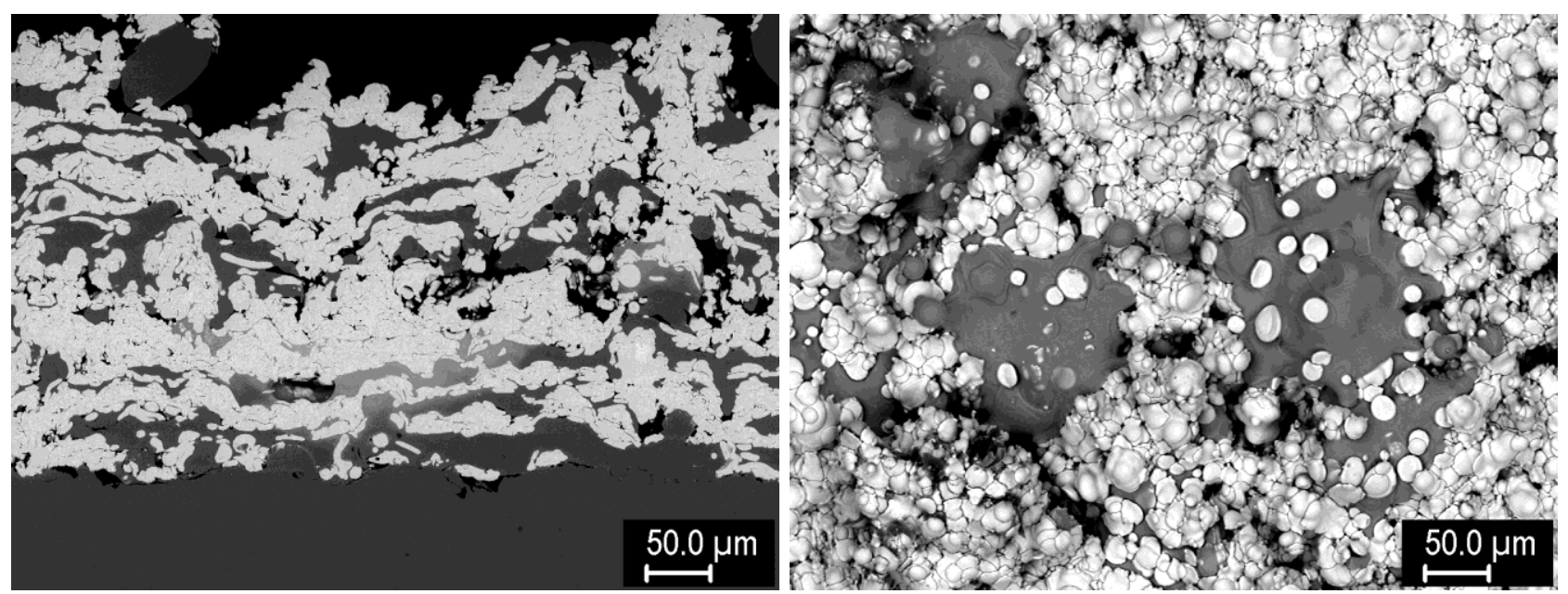

Figure 5 a) cross section of a tungsten-steel coating sprayed on a rotating cooled holder, showing a region of strong interdiffusion (center, near the interface with substrate); steel enrichment by tungsten is indicated by a brighter shade; b) surface of the same coating.
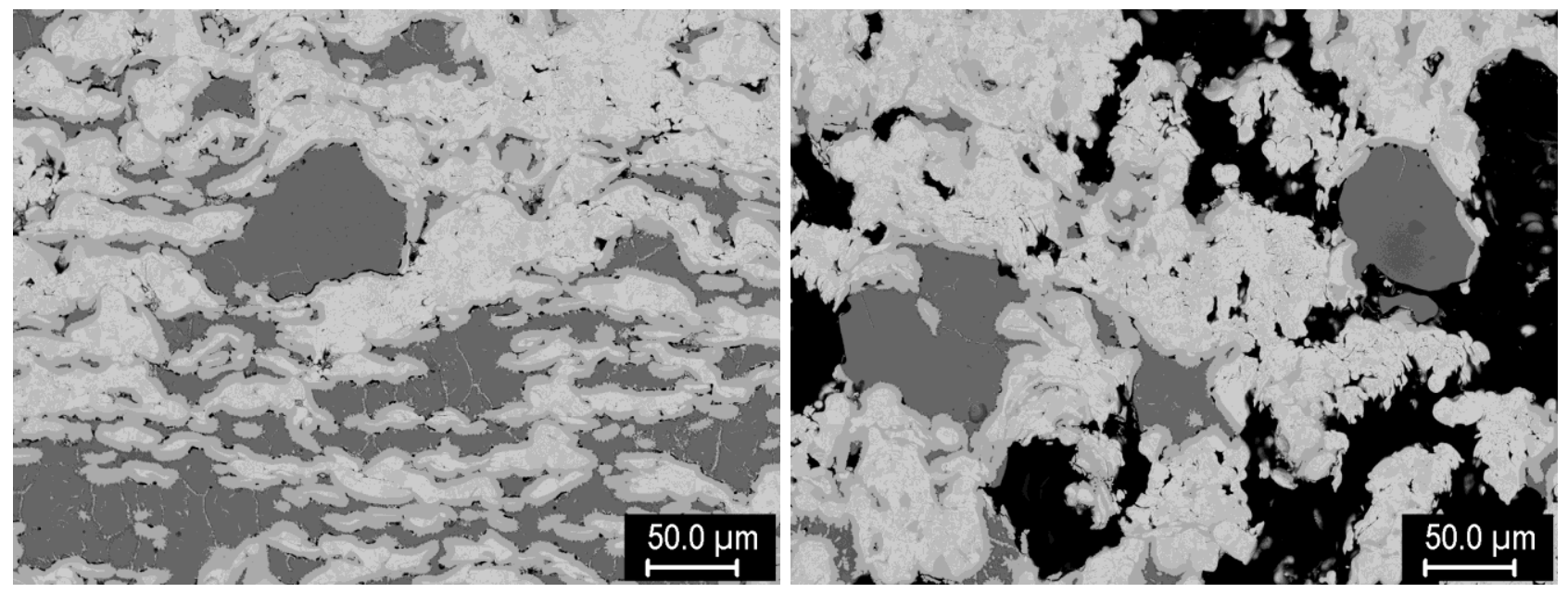

Figure 6 Cross section of a tungsten-steel coating sprayed on a cooled holder without rotation; a) dense region near the substrate, b) porous region farther away from the substrate.

\subsection{Tungsten-chromium composites}

The tungsten-steel composites might encounter the issue of intermetallic formation upon thermal exposure. These are generally undesirable, as they are brittle and reduce the thermal conductivity [17]. Even when not formed during production, such as in plasma sprayed coatings [7,9], they may form when applied in a fusion reactor at elevated temperature. In spark plasma sintered composites, they formed at temperatures around $1100^{\circ} \mathrm{C}$ [18]. They were also present in composites prepared by ultrafast sintering and have grown already at $300{ }^{\circ} \mathrm{C}$ annealing temperature [19]. Therefore, tungsten-chromium may be considered as an alternative, as chromium properties are rather similar to stainless steel (Table 1). The slightly higher melting point and thermal conductivity of chromium and lower coefficient of thermal expansion are even more favorable for the application in plasma facing components.

Representative cross sections of W-Cr composites are shown in Figure 7. Figure 7a) shows one of the earlier coatings, sprayed from a $25 \% \mathrm{Cr}$ mixture on a graphite substrate. Figure $\mathbf{7 b}$ ) shows an optimized thicker 
coating sprayed with an additional heating by the plasma torch between the individual deposition passes, to enhance the interparticle bonding. In both cases, relatively dense coatings were formed (porosity $=4$ and $2 \%$, respectively) with even mixing of the tungsten and chromium particles. Mutual interdiffusion was observed according to local EDS, Cr content was around 3-4\% in the W-rich particles and around $60-90 \%$ in $\mathrm{Cr}$-rich ones. In both coatings, the $\mathrm{Cr}$ content was about the same as in the feedstock.

Table 1 Comparison of steel, chromium and tungsten properties (near room temperature) [15].

\begin{tabular}{|c|c|c|c|}
\hline Property & AISI 410 steel & Chromium & Tungsten \\
\hline Melting temperature $\left({ }^{\circ} \mathrm{C}\right)$ & $\sim 1500$ & 1860 & $\sim 3400$ \\
\hline Density $\left(\mathrm{g} / \mathrm{cm}^{3}\right)$ & 7.80 & 7.19 & 19.3 \\
\hline Young's modulus (GPa) & 200 & 248 & 400 \\
\hline $\begin{array}{l}\text { Thermal expansion coefficient } \\
\left(10^{-6} /{ }^{\circ} \mathrm{C}\right)\end{array}$ & 9.9 & 6.2 & 4.4 \\
\hline Thermal conductivity (W/m.K) & 25 & 69 & 163 \\
\hline
\end{tabular}
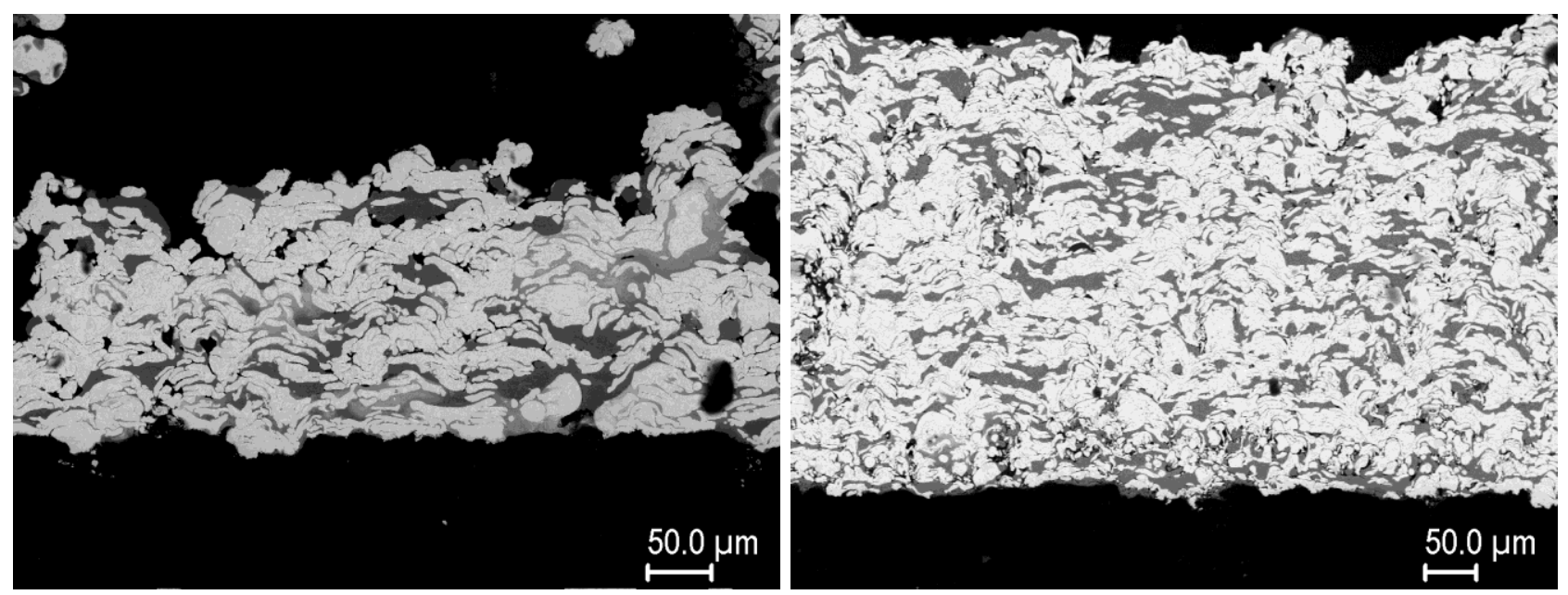

Figure 7 Cross sections of tungsten-chromium coatings; a) mixture with $25 \% \mathrm{Cr}$ on a graphite substrate, b) mixture with $25 \% \mathrm{Cr}$ on a graphite substrate, sprayed with additional torch heating.
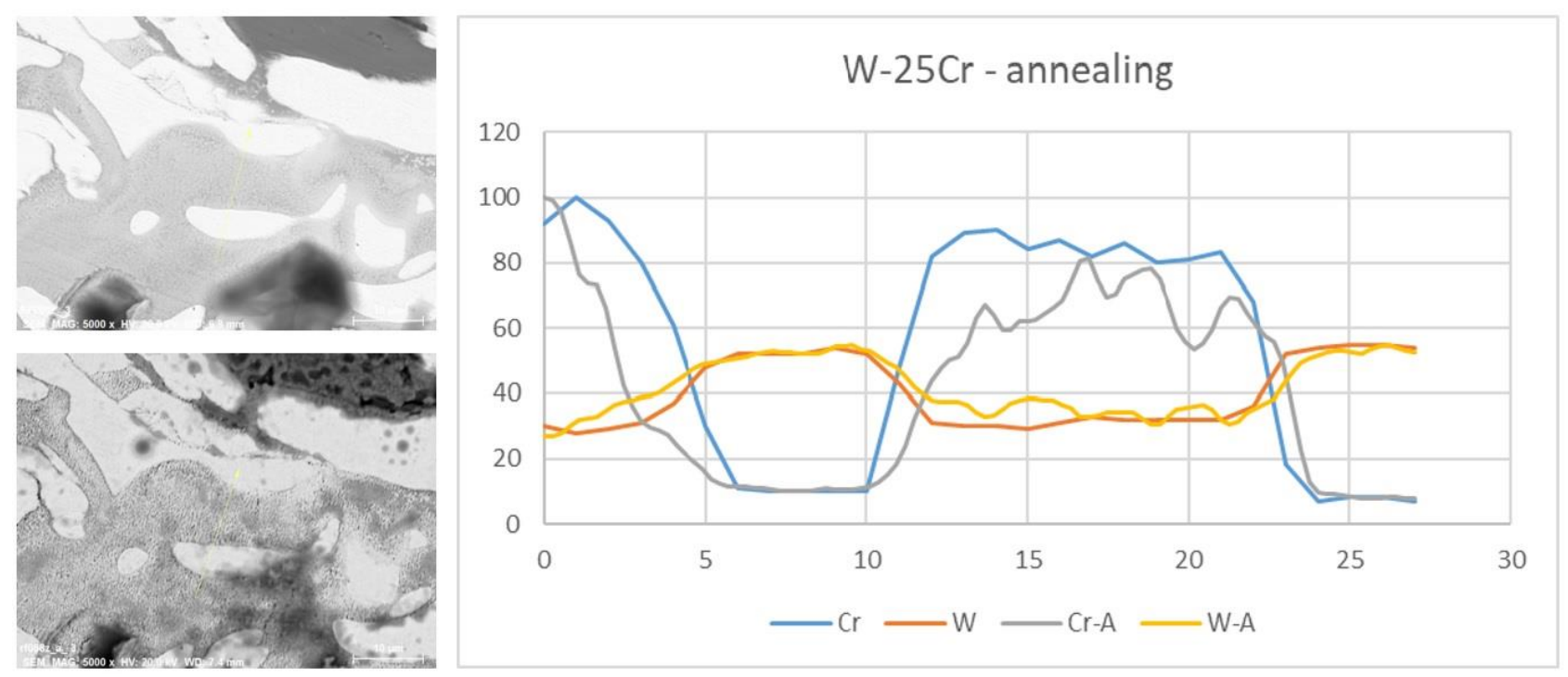

Figure 8 Cross sections of tungsten-chromium coatings before (a) and after (b) annealing at $1000{ }^{\circ} \mathrm{C} ; \mathrm{c}$ ) relative concentration profiles of $\mathrm{W}$ and $\mathrm{Cr}$ across the lines shown in a) and b). 
Thermal stability of the $\mathrm{W}-\mathrm{Cr}$ coating from Figure 7a) was investigated by EDS line analysis at the same location before and after annealing. Figure $\mathbf{8 a}$ ) and b) shows the region of interest; Figure $\mathbf{8 c}$ ) shows the relative concentration profiles of $\mathrm{W}$ and $\mathrm{Cr}$. From these, one can see that interdiffusion takes place only very locally, in a region smaller than a splat thickness. By comparing Figures $\mathbf{8 a}$ ) and $\mathbf{b}$ ), one can see that the Wrich and $\mathrm{Cr}$-rich phase boundaries are preserved. Some microporosity formation is observed in the $\mathrm{Cr}$-rich phase. Therefore, one can conclude that this material combination exhibits higher thermal stability than the Wsteel composites presented in [19].

\section{CONCLUSION}

Tungsten-steel and tungsten-chromium composites were prepared by RF-ICP plasma spraying, with the potential application as stress-relieving interlayers in plasma facing components of fusion reactors. This paper presents a 'work in progress', as only initial optimization of the spraying process was carried out. Tungstensteel coatings feature various degree of intermixing of the two phases and local inhomogeneities in porosity. In various coatings, the $\mathrm{Fe}_{7} \mathrm{~W}_{6}$ intermetallic is present or absent, probably as a consequence of different deposition temperatures. The absence of substrate temperature measurement for the initial optimization trials has prevented its tighter control, but is now installed and the temperature effects are the subject of ongoing investigation. Some of the abovementioned issues might be related to the change in spraying geometry and substrate material. Tungsten-chromium composites generally feature higher density and homogeneity than the tungsten-steel ones. While the annealing experiment was not carried out at identical conditions as for the tungsten-steel composites, its results suggest a better thermal stability of the tungsten-chromium composite. Therefore, it can be considered as a prospective alternative to tungsten-steel.

\section{ACKNOWLEDGEMENTS}

This work was supported by Czech Science Foundation through grant no. GA19-14339S. Part of the work has been carried out within the framework of the EUROfusion Consortium and has received funding from the Euratom research and training programme 2019-2020 under grant agreement no. 633053.

\section{REFERENCES}

[1] LINKE, J., DU, J., LOEWENHOFF, T., PINTSUK, G., SPILKER, B., STEUDEL, I., AND WIRTZ, M. Challenges for plasma-facing components in nuclear fusion. Matter and Radiation at Extremes. 2019, vol. 4, paper no. 056201.

[2] PINTSUK, G. Tungsten as a Plasma-Facing Material, In: KONINGS, R.J.M., ed. Comprehensive Nuclear Materials. Amsterdam: Elsevier, 2012, pp. 551-581.

[3] RIETH, M., DUDAREV, S.L., GONZALEZ DE VICENTE, S.M., AKTAA, J., AHLGREN, T., ANTUSCH, S., ARMSTRONG, D.E.J., BALDEN, M., BALUC, N., BARTHE, M.F., BASUKI, W.W., BATTABYAL, M., BECQUART, C.S., BLAGOEVA, D., BOLDYRYEVA, H., BRINKMANN, J., CELINO, M., CIUPINSKI, L., CORREIA, J.B., DE BACKER, A., DOMAIN, C., GAGANIDZE, E., GARCIA-ROSALES, C., GIBSON, J., GILBERT, M.R., GIUSEPPONI, S., GLUDOVATZ, B., GREUNER, H., HEINOLA, K., HOESCHEN, T., HOFFMANN, A., HOLSTEIN, N., KOCH, F. , KRAUSS, W., LI, H., LINDIG, S., LINKE, J., LINSMEIER, C.H., LOPEZ-RUIZ, P., MAIER, H., MATEJICEK, J., MISHRA, T.P., MUHAMMED, M., MUNOZ, A., MUZYK, M., NORDLUND, K., NGUYEN-MANH, D., OPSCHOOR, J., ORDAS, N., PALACIOS, T., PINTSUK, G., PIPPAN, R., REISER, J., RIESCH, J. , ROBERTS, S.G., ROMANER, L., ROSINSKI, M., SANCHEZ, M., SCHULMEYER, W., TRAXLER, H., URENA, A., VAN DER LAAN, J.G., VELEVA, L., WAHLBERG, S., WALTER, M., WEBER, T., WEITKAMP, T., WURSTER, S., YAR, M.A., YOU, J.H., ZIVELONGHI, A. Recent Progress in Research on Tungsten Materials for Nuclear Fusion Applications in Europe. Journal of Nuclear Materials. 2013, vol. 432, no. 1-3, pp. 482-500.

[4] HEUER, S., COENEN, J.W., PINTSUK, G., MATEJICEK, J., VILÉMOVÁ, M., LINSMEIER, CH. Overview of challenges and developments in joining tungsten and steel for future fusion reactors. Physica Scripta. 2020, vol. T171, paper no. 014028. 
[5] MATEJICEK, J., NEVRLA, B., VILEMOVA, M., BOLDYRYEVA, H. Overview of Processing Technologies for Tungsten-Steel Composites and FGMs for Fusion Applications. Nukleonika. 2015, vol. 60, no. 2, pp. $267-273$.

[6] MATEJICEK, J., CHRASKA, P., LINKE, J. Thermal Spray Coatings for Fusion Applications - Review. Journal of Thermal Spray Technology. 2007, vol. 16, no. 1, pp. 64-83.

[7] MATĚJÍČEK, J., BOLDYRYEVA, H. Processing and Temperature-Dependent Properties of Plasma Sprayed Tungsten-Stainless Steel Composites. Physica Scripta. 2009, vol. T138, paper no. 014041

[8] EMMERICH, T., QU, D.D., VASSEN, R., AKTAA, J. Development of W-Coating With Functionally Graded W/Eurofer-Layers for Protection of First-Wall Materials. Fusion Engineering and Design. 2018, vol. 128, pp. 58-67.

[9] HEUER, S., MATĚJíČEK, J., VILÉMOVÁ, M., KOLLER, M., ILLKOVÁ, K., VEVERKA, J., WEBER, T., PINTSUK, G., COENEN, J.W., LINSMEIER, CH. Atmospheric Plasma Spraying of Functionally Graded Steel/Tungsten Layers for the First Wall of Future Fusion Reactors. Surface \& Coatings Technology. 2019, vol. 366, pp. 170-178.

[10] MATĚJíČEK, J., KAVKA, T., BERTOLISSI, G., CTIBOR, P., VILÉMOVÁ, M., MUŠÁLEK, R., NEVRLÁ, B. The Role of Spraying Parameters and Inert Gas Shrouding in Hybrid Water-Argon Plasma Spraying of Tungsten and Copper for Nuclear Fusion Applications. Journal of Thermal Spray Technology. 2013, vol. 22, no. 5, pp. 744-755.

[11] CIZEK, J., KLECKA, J., VILEMOVA, M., MATEJICEK, J., VEVERKA, J., MUSALEK, R., LUKAC, F., KONDAS, J., ZLATNIK, R. Armor W-Cr coatings for plasma-facing components in tokamaks by cold spray and RF-ICP. In New Waves of Thermal Spray Technology for Sustainable Growth: International Thermal Spray Conference and Exposition. Materials Park: ASM International, 2019, pp. 535-540.

[12] CIZEK, J., VILEMOVA, M., LUKAC, F., KOLLER, M., KONDAS, J., SINGH, R. Cold Sprayed Tungsten Armor for Tokamak First Wall. Coatings. 2019, vol. 9, no. 12, paper no. 836.

[13] BOULOS M.I. RF Induction Plasma Spraying: State-of-the-Art Review. Journal of Thermal Spray Technology. 1992, vol. 1, no. 1, pp. 33-40.

[14] KLEČKA, J., MUŠÁLEK, R., VILÉMOVÁ, M., LUKÁČ, F. On tungsten spraying using inductively coupled plasma system - First results. In METAL 2017: 26th International Conference on Metallurgy and Materials. Ostrava: TANGER, 2017, pp. 1321-1326.

[15] MATWEB, LLC. MatWeb - Material Property Data [online]. [viewed 2020-03-06]. Available from: http://www.matweb.com.

[16] WINTER, M. WebElements [online]. [viewed 2020-03-06]. Available from: http://www.webelements.com.

[17] MATEJICEK, J., NEVRLA, B., CECH, J., VILEMOVA, M., KLEVAROVA, V., HAUSILD, P. Mechanical and Thermal Properties of Individual Phases Formed in Sintered Tungsten-Steel Composites. Acta Physica Polonica A. 2015, vol. 128, no. 4, pp. 718-721.

[18] KOLLER, M., KRUISOVA, A., MUSALEK, R., MATEJICEK, J., SEINER, H., LANDA, M. On the Relation Between Microstructure and Elastic Constants of Tungsten/Steel Composites Fabricated by Spark Plasma Sintering. Fusion Engineering and Design. 2018, vol. 133, pp. 51-58.

[19] HEUER, S., LI, B.-S., ARMSTRONG, D.E.J., ZAYACHUK, Y., LINSMEIER, CH. Microstructural and micromechanical assessment of aged ultra-fast sintered functionally graded iron/tungsten composites. Materials and Design. 2020, vol. 191, paper no. 108652. 